\title{
Hubungan Kadar C-Reactive Protein dan Kadar Feritin Serum pada Gizi Kurang Usia 7-9 Tahun
}

\author{
Endang Dewi Lestari, Fadhilah Tia Nur, Harsono Salimo \\ Bagian Ilmu Kesehatan Anak Fakultas Kedokteran Universitas Sebelas Maret-RSUD Dr. Moewardi, Surakarta
}

\begin{abstract}
Latar belakang. Kekurangan mikronutrien masih banyak terjadi di negara berkembang. Protein fase akut meningkat secara signifikan selama proses inflamasi akut.

Tujuan. Penelitian bertujuan untuk menganalisis hubungan antara kadar $C$-reactive protein (CRP) dengan kadar feritin serum pada anak dengan gizi kurang usia 7-9 tahun di sekolah dasar di Surakarta.

Metode. Penelitian uji potong lintang dilakukan di 10 SD di Surakarta pada 217 anak gizi kurang usia 7-9 tahun. Hubungan antara kadar CRP dan kadar feritin serum dinilai menggunakan analisis regresi logistik. Analisis statistik menggunakan SPSS versi 17.0.

Hasil. Analisis regresi logistik menunjukkan terdapat hubungan secara signifikan antara rata-rata kadar feritin serum dengan kadar CRP>5 mg/L $(\mathrm{OR}=6,38, p=0,006,95 \%$ CI 1,7-23,9).

Kesimpulan. Terdapat hubungan yang bermakna antara kadar CRP dengan kadar feritin serum.

Sari Pediatri 2011;13(4):275-79.
\end{abstract}

Kata kunci: kadar CRP, feritin serum, gizi kurang

K

ekurangan zat-zat mikronutrien terutama zat besi merupakan masalah utama di sebagian besar negara yang sedang berkembang. berkembang kekurangan zat besi. ${ }^{1}$ Besi merupakan mineral penting dalam tubuh manusia. Besi berperan penting dalam pembentukan sel-sel darah merah, pengangkutan elektron, imunitas tubuh, serta proses tumbuh kembang terutama motorik dan mental. ${ }^{2,3}$ Kekurangan besi akan mengakibatkan beberapa

Alamat korespondensi:

Dr. Endang Dewi Lestari, Sp.A(K). Staf UPF. Anak. Bag.IKA RSUD Dr. Moewardi Jl. Kol Sutarto 132 Solo Jawa Tengah. TeLp. 0271- 666866 kelainan, salah satu kelainan adalah gangguan fungsi imunitas tubuh. ${ }^{1}$

Kekurangan zat besi berhubungan dengan kejadian infeksi dan inflamasi, hal ini digambarkan dengan perubahan kadar feritin serum, zat besi serum, dan saturasi transferin pada saat fase akut. ${ }^{4}$ Beberapa penelitian menunjukkan beberapa penanda proses inflamasi yang dapat digunakan untuk menggambarkan proses inflamasi yang berkaitan dengan perubahan kadar zat besi dalam tubuh..$^{-7}$ Penelitian terbaru menunjukkan penanda protein fase akut yang paling sering yaitu $C$-reactive protein (CRP) dan $\alpha_{1}$-acid glycoprotein (AGP) pada bayi dan anak. ${ }^{5}$

Protein fase akut memegang peran dalam proses inflamasi yang kompleks. Konsentrasi protein fase akut meningkat secara signifikan selama proses 
inflamasi akut misalnya tindakan pembedahan, infark miokard, infeksi, dan tumor. Peningkatan tersebut disebabkan oleh peningkatan sintesis di hati, namun tidak dapat digunakan untuk menentukan penyebab inflamasi. Pengukuran protein fase akut dapat digunakan untuk mengamati progresivitas dari inflamasi serta melihat respon terapi dengan menilainilai kapan protein fase akut mulai meningkat dan kapan kadar yang tertinggi tercapai. ${ }^{8}$

Penelitian ini dilakukan untuk menganalisis hubungan antara kadar CRP dengan kadar feritin serum pada anak dengan gizi kurang usia 7-9 tahun di sekolah dasar di Surakarta.

\section{Metode}

Telah dilakukan penelitian potong lintang pada 217 anak untuk menganalisis hubungan antara kadar $C$-reactive protein (CRP) dengan kadar feritin serum pada anak dengan gizi kurang. Subjek penelitian adalah semua anak usia 7-9 tahun dengan gizi kurang di sekolah dasar Surakarta dengan rata-rata pendapatan orang tuanya sebesar Rp 500.000,-. Pengambilan sampel secara purposive sampling. Kriteria inklusi meliputi usia 7-9 tahun, gizi kurang $\left(\mathrm{P} 3^{\text {rd }}<\mathrm{bb} / \mathrm{u}<\mathrm{P} 10^{\text {th }}, \mathrm{CDC} 2000\right)$, tidak menderita penyakit ginjal, penyakit tiroid, thalassemia, cacat bawaan, memahami informasi penelitian secara tertulis dan menandatangani informed consent. Penelitian ini telah disetujui oleh Panitia Kelaikan Etik RS. Dr. Moewardi, Surakarta.

Subjek penelitian dipilih adalah anak dengan umur 7 sampai dengan 9 tahun, dimaksudkan untuk menyamakan populasi dan untuk menghindari masa pertumbuhan cepat (growth spurt) yang dimulai pada usia 9 tahun. Gizi kurang apabila status antropometri menurut berat badan terhadap umur berada di bawah persentil 10 pada kurva CDC tahun 2000. Berat badan ditimbang dengan timbangan digital, penimbangan dilakukan dua kali dan diambil rata-ratanya. Tinggi badan diukur dengan menggunakan microtoire, pengukuran dilakukan dua kali dan diambil rataratanya. Sekolah dasar yang dipilih berdasarkan kondisi ekonomi dengan melihat pendapatan orang tua kurang dari Rp 500.000 per bulan. Data didapat dari Dinas Pendidikan Nasional Kota Surakarta. Pengambilan sampel darah diambil dari darah vena. Kadar CRP diukur menggunakan metode immunoturbidimetri,
CRP plasma meningkat apabila $>5 \mathrm{mg} / \mathrm{L}$. Feritin diukur menggunakan metode ELISA, meningkat apabila lebih besar dari kadar rata-rata.

Variabel bebas pada penelitian ini adalah kadar CRP sedang variabel tergantung adalah kadar feritin. Hubungan antara kadar CRP dengan kadar feritin serum diolah menggunakan analisis regresi logistik. Analisis multivariat digunakan untuk menyesuaikan faktor kovariat yaitu jenis kelamin. Hasil signifikan apabila $\mathrm{p}<0,05$. Data diolah dengan menggunakan SPSS 17.0.

\section{Hasil}

Subyek pada penelitian 217 anak dengan gizi kurang berusia 7-9 tahun. Terdapat 52\% anak laki-laki dan $48 \%$ anak perempuan. Karakteristik dasar subyek penelitian tertera pada Tabel 1 .

Karakteristik kadar CRP dan feritin serum tertera pada Tabel 2. Rerata kadar CRP 1,44 mg/L dengan standar deviasi (SB) 3,92 mg/L. Rerata kadar feritin $29,55 \mu \mathrm{g} / \mathrm{L}$ dengan SB 18,84 $\mu \mathrm{g} / \mathrm{L}$.

Hubungan antara kadar CRP dengan kadar feritin serum diolah menggunakan analisis regresi logistik. Variabel bebas adalah kadar CRP, variabel tergantung adalah kadar feritin dan variabel perancu adalah jenis kelamin. Tabel 3 menunjukkan hubungan antara kadar rerata feritin serum dan CRP $>5 \mathrm{mg} / \mathrm{L}$ serta jenis kelamin. Berdasarkan analisis regresi logistik menunjukkan terdapat hubungan secara signifikan antara kadar feritin serum dengan kadar CRP, dan tidak terdapat hubungan secara

Tabel 1. Karakteristik dasar subyek penelitian $(\mathrm{n}=217)$

\begin{tabular}{lcc}
\hline Karakteristik dasar & $\mathrm{n}$ & $\%$ \\
\hline Umur (tahun) & & \\
$\quad 7-8$ & 107 & 49 \\
$\quad 8-9$ & 110 & 51 \\
Jenis kelamin & & \\
$\quad$ Laki-laki & 112 & 52 \\
$\quad$ Perempuan & 105 & 48 \\
Kadar CRP (mg/L) & & \\
$\quad>5$ & 13 & 6 \\
$\quad<5$ & 204 & 94 \\
Kadar rerata feritin (mg/L) & & \\
$\quad>29,5$ & 80 & 37 \\
$\quad<29,5$ & 137 & 63 \\
\hline
\end{tabular}


Tabel 2. Karakteristik kadar CRP dan feritin serum $(\mathrm{n}=217)$

\begin{tabular}{lccc}
\hline Variabel & Median & Rerata & SB \\
\hline Kadar CRP & 0,36 & 1,44 & 3,92 \\
Kadar Ferritin & 27,1 & 29,55 & 18,84 \\
\hline
\end{tabular}

Tabel 3. Hubungan antara kadar rerata feritin serum dan CRP

\begin{tabular}{lccc}
\hline \multirow{2}{*}{ Variabel } & \multicolumn{3}{c}{ Rerata feritin serum $(\mathrm{mg} / \mathrm{L})$} \\
\cline { 2 - 4 } & OR & $\mathrm{p}$ & $95 \% \mathrm{CI}$ \\
\hline *CRP & 6,38 & 0,006 & $1,7-23,9$ \\
Jenis kelamin & 0,71 & 0,228 & $0,4-1,2$ \\
\hline
\end{tabular}

${ }^{*} \mathrm{CRP}=(>5 \mathrm{mg} / \mathrm{L})$

Tabel 4. Analisis multivariat antara kadar dan jenis kelamin terhadap kadar rerata feritin serum

\begin{tabular}{lccc}
\hline & \multicolumn{3}{c}{ Rerata feritin serum $(\mathrm{mg} / \mathrm{L})$} \\
\cline { 2 - 4 } & OR & $\mathrm{p}$ & $95 \% \mathrm{CI}$ \\
\hline${ }^{*} \mathrm{CRP}$ & 6,33 & 0,006 & $1,6-23,8$ \\
Jenis kelamin & 0,71 & 0,251 & $0,4-1,2$ \\
\hline
\end{tabular}

${ }^{*} \mathrm{CRP}=(>5 \mathrm{mg} / \mathrm{L})$

signifikan antara kadar feritin serum dengan jenis kelamin.

Pada Tabel 4 analisis multivariat menunjukkan CRP mempunyai OR 6,33 ( $p=0,006$; $95 \%$ CI 1,6 - 23,8), sedangkan jenis kelamin mempunyai OR $0,71(p=0,251 ; 95 \%$ CI $0,4-1,2)$. Berdasarkan hasil tersebut disimpulkan terdapat hubungan signifikan antara peningkatan kadar feritin serum dengan peningkatan kadar CRP.

\section{Pembahasan}

Beberapa penelitian menunjukkan penanda proses inflamasi yang dapat digunakan untuk menggambarkan proses inflamasi yang berkaitan dengan perubahan kadar zat besi dalam tubuh..$^{5-7}$ Penelitian terbaru menunjukkan penanda protein fase akut yang paling sering yaitu $C$-reactive protein (CRP) dan $\alpha_{1}$-acid glycoprotein (AGP) pada bayi dan anak-anak. ${ }^{5}$ Penelitian Beard dkk, ${ }^{9}$ membuktikan hubungan antara kadar CRP dan kadar feritin serum. Temuan kami sesuai dengan penelitian Beard $\mathrm{dkk}^{9}$ yang memperlihatkan hubungan signifikan antara peningkatan kadar feritin serum dengan kadar protein fase akut (CRP dan AGP).

Kadar CRP akan meningkat cepat pada infeksi, disebut respon fase akut. Peningkatan CRP berhubungan dengan peningkatan konsentrasi interleukin-6 (IL-6) di dalam plasma yang sebagian besar diproduksi oleh makrofag. Makrofag merupakan sel imun yang berperan langsung dengan kadar besi dalam tubuh manusia. Makrofag membutuhkan zat besi untuk memproduksi highly toxic hydroxyl radical, juga merupakan tempat penyimpanan besi yang utama pada saat terjadi proses inflamasi. Sitokin, radikal bebas, serta protein fase akut yang dihasilkan oleh hati akan mempengaruhi homeostasis besi oleh makrofag dengan cara mengatur ambilan dan keluaran besi sehingga akan memicu peningkatan retensi besi dalam makrofag pada saat terjadi inflamasi. Besi juga mengatur aktivitas sitokin, proliferasi, dan aktivitas limfosit sehingga diferensiasi dan aktivasi makrofag akan terpengaruh. ${ }^{10}$

Protein fase akut memegang peran dalam proses inflamasi yang kompleks. Konsentrasi protein fase akut meningkat secara signifikan selama proses inflamasi akut karena tindakan pembedahan, infark miokard, infeksi, dan tumor. Peningkatan disebabkan oleh sintesis di hati, namun tidak dapat digunakan untuk menentukan penyebab inflamasi. Pengukuran protein fase akut dapat digunakan untuk mengamati progresivitas dari inflamasi serta melihat respon terapi dengan melihat nilai protein fase akut saat mulai meningkat dan kadar yang tertinggi. ${ }^{8}$

Kadar feritin serum tidak dapat menggambarkan indeks cadangan besi dalam tubuh pada saat terjadi kerusakan sel tubuh. Feritin diproduksi oleh sistem reticulo endotelial, yang berperan penting dalam proses metabolisme zat besi saat pembentukan hemoglobin dari sel darah merah senescent. Proses inflamasi dan infeksi akut akan memicu blokade pelepasan zat besi sehingga akan menurunkan kadar zat besi serum. Peningkatan kadar feritin serum menggambarkan respons klinis terhadap mikroorganisme. ${ }^{11-14}$ Peningkatan kadar feritin serum terlihat pada ensefalitis dan sebanding dengan peningkatan protein fase akut. ${ }^{15}$ Peningkatan kadar feritin serum juga terlihat pada kasus infeksi virus dengue. ${ }^{16}$

Gizi kurang berisiko mengalami kekurangan zat gizi mikro. Kekurangan zat gizi mikro akan meningkatkan risiko terjadinya infeksi. Pada penelitian kami tidak didapatkan klinis infeksi pada semua subjek penelitian, sehingga faktor infeksi 
sebagai faktor perancu dapat disingkirkan. Semua subjek penelitian adalah gizi kurang sehingga berisiko mudah terjadi infeksi dan berisiko terjadi peningkatan protein fase akut. Hasil kadar CRP dan kadar feritin pada penelitian ini kadarnya meningkat meskipun kadar feritin masih berada dalam rentang normal. Perubahan konsentrasi kadar feritin pada saat terjadi respon fase akut berbeda dengan zat gizi mikro lainnya seperti vitamin A, zink. Hal tersebut disebabkan karena feritin merupakan salah satu jenis protein fase akut. Adanya dua hal yang berlawanan mengenai perubahan kadar zat besi saat terjadinya infeksi memberikan gambaran bahwa kadar feritin tidak menggambarkan kadar besi darah yang sesungguhnya pada saat terjadinya infeksi. Parameter zat besi yang dapat menggambarkan kadar besi dalam tubuh dan tidak terpengaruh oleh adanya infeksi yaitu Serum Transferrin Receptor (sTfR). sTfR dapat digunakan untuk menilai defisiensi besi pada tahap awal, namun kadar sTfR meningkat dengan cepat apabila terdapat kelebihan cadangan besi. ${ }^{6,17}$

Terdapat beberapa kelemahan pada penelitian kami. Penelitian kami merupakan uji potong lintang, sehingga peneliti tidak dapat menentukan sebab dan akibat. Kelemahan kedua yaitu peneliti hanya berdasarkan satu kali pengambilan sampel darah, sehingga peneliti tidak dapat melihat perubahan kadar CRP dan kadar feritin serum yang dapat terjadi pada saat terdapat proses inflamasi.

Terdapat hubungan yang bermakna antara kadar CRP dengan kadar feritin serum pada anak dengan gizi kurang usia 7-9 tahun di Surakarta. Anak yang mengalami peningkatan kadar CRP mempunyai kesempatan 6 kali mengalami peningkatan kadar feritin serum.

\section{Ucapan terima kasih}

Penelitian ini didukung oleh PT. Nestle Indonesia. Ucapan terima kasih penulis sampaikan kepada Dr. Saptawati Bardosono, dr., MSc; Leilani Lestarina, dr; Prof. Bhisma Murti, dr., MPH, M.Sc., Ph.D atas semua bantuan dan kontribusi dalam penelitian ini. Terima kasih kepada laboratorium Prodia yang telah mengambil sampel darah subjek penelitian dan kepada anak-anak/orangtua yang telah berpartisipasi pada penelitian ini, serta kepada kepala sekolah dan guru yang membantu penelitian.

\section{Daftar pustaka}

1. Dijkhuizen MA, Wieringa FT. Effects of iron and zinc supplementation in Indonesian infants on micronutrients status and growth. Am J Clin Nutr 2001;131:2860-5.

2. Berger A. Science commentary: what does zink do. British Med J 2002;325:1062.

3. Ohls RK, Christensen RD. Development of the hematopoetic system. Dalam: Behrman RE, Jenson HB, Kliegman RM, penyunting. Nelson Textbook of Pediatrics. Edisi ke-17. Philadelpia: WB Saunder; 2004.h.1602-5.

4. Thomas C, Thomas L. Biochemical markers and hematologic indices in the diagnosis of functional iron deficiency. Clin Chem 2002;48:1066-76.

5. Asobayire FS, Adou P, Davidson L, Cook JD, Hurrel RF. Prevalence of iron deficiency with and without concurrent anemia in population groups with high prevalences of malaria and other infections: a study in Cote d'Ivoire. Am J Clin Nutr 2001;74:776-82.

6. Wieringa FT, Dizkhuizen MA, West CE, NorthropClewes CA, Muhilal. Estimation of the effect of the acute phase response on indicators of micronutrients status in Indonesian infants. J Nutr 2001;132:3061-6.

7. Baillie FJ, Morrison AE, Fergus I. Soluble transferring receptor: a discriminating assay for iron deficiency. Clin Lab Haematol 2003;25:353-7.

8. Pepys MB. C-reactive protein, fifty years on. Lancet 2007;1:653-7.

9. Beard JL, Murray-Kolb LE, Rosales FJ. Interpretation of serum ferritin concentrations as indicators of totalbody iron stores in survey populations: the role of biomarkers for the acute phase respons. Am J Clin Nutr 2006;84:1498-505.

10. Theurl I, Fritsche G. The macrophage: a cellular factory at the interphase between iron and immunity for the control of infections. BioMetals 2005;18:359-67.

11. Wormwood M. Serum ferritin. Crit Rev Clin Lab Sci 2001;10:171-204.

12. Griffith E. Iron and bacterial virulence: a brief overview. Biol Met 1991;4:7-13.

13. Wooldridge KG, Williams PH. Iron uptake mechanism of pathogenic bacteria. Microbiol Rev 1993;12:32548.

14. Krol V, Cunha BA. Diagnostic significance of serum ferritin levels in infectious and non-infectious diseases. Infect Dis Pract 2003;27:199-200. 
15. Cunha BA, Sachdev B, Canario D. Serum ferritin levels in West Nile encephalitis. Clin Microbiol Infect 2008;10:184-6.

16. Chaiyaratana W, Chuansumrit A, Kalayanee A. Serum ferritin levels in children with dengue infection. Southeast Asian J Trop Med Public Health 2008;39:832-6.

17. Cook JD, Skikne BS, Baynes RD. Serum transferring receptor. Annu Rev Med 1993;44:63-74. 